\title{
Educational Research and Developing Countries; facts, figures and some conceptual approaches for analysing interactions between funding, products and users
}

\author{
S. I. Cohen and H. Reiff
}

\section{Introduction}

Although there has been a remarkable surge in knowledge on educational research in the development context (ERDC) in the past few years, most of this knowledge is very much tied to case studies, is descriptive and fragmented in nature and is not yet systematised within an analytical framework. Current discussions on how one might increase the utility of the resources available to educational research are handicapped by this lack.

This article presents factual material on issues of funding and research, and discusses a few analytical approaches which may promote an effective integration of the accumulated experience in ERDC and a more systematic discussion of policy towards educational research. We hope to contribute to the formation of a badly needed operational conceptual framework for guiding collaborative development.

Indeed, ERDC can be viewed as the systematic and disciplined generation of knowledge about educational facts and problems [Court and Latapi 1979]. In addition, it is a multidimensional process of negotiations, investigation and dissemination which involves institutions and persons from advanced and developing countries. In practice, the advanced country or the international agency is the donor and the developing country is recipient. Cases where a collaborative educational research effort occurs in an advanced country are infrequent.

In general, a collaborative educational research project links three kinds of actors: the sponsoring institution or funding agency, the analyst and the user. Each actor can be described as having a pre-set responsibility. Accountability for an actor can be interpreted broadly as the ex ante incorporation of the pre-set responsibility into his action, or the ex post justification of his action in terms of the institutionally defined responsibility. For example, the sponsoring institution or funding agency is supposed to observe administrative and policy guidelines in executing its functions of initiating, supporting, monitoring and evaluating a project. Likewise, the analyst is held accountable in meeting certain obligations in the delivery of the product and maintaining certain levels of quality. The user, whether direct or ultimate, is also accountable in the sense of whether he is making good, bad or no use of the process and results of educational research.

These may be called accountabilities from the involved actors' points of view. In addition, there is another type of accountability which is difficult to specify in a situation where there is no consensus. This is social accountability. It is essential to appreciate this distinction.

\section{International Interactions in Educational Research}

ERDC can be described as the meeting place of a sponsor or funder, analysts, and users from an advanced country (donor), and a sponsor, analysts and users from a developing country (recipient).

Actors in the donor country do coordinate their positions. Such a coordination is represented by interaction $\mathrm{X}$ in Figure 1. Actors in the recipient country coordinate their positions too, represented as $\mathrm{Y}$ in the figure.

Because three actors on each side are involved this leads to nine additional cross-country interactions as demonstrated by $Z$.

The authors wish to emphasise their responsibility for the choice and presentation of the facts and the opinions, which are not necessarily those of UNESCO. 
Figure 1

\section{Basic Interactions in ERDC}

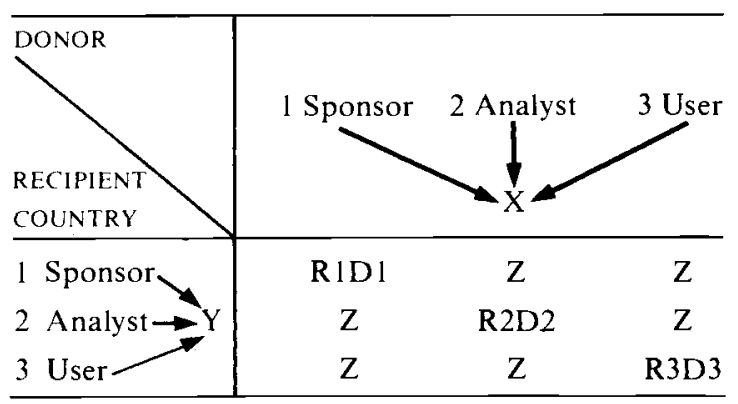

The sponsor and analyst are familiar actors and their comprehension requires little elaboration. In the narrowest sense, the user is an independent policy maker who is approached by the researcher with the results of his research. In a wider sense, the analystplanner duality disappears in favour of a dialectical, and sometimes switching relationship. In the widest sense, users of research become those influenced by its process, and all those who have read or heard of its results and acted accordingly by changing their attitudes. The latter can be called the 'ultimate consumers'.

To maintain an operational framework it is essential to hold an identifiable notion of users. Users of educational research will be identified here solely as the audience involved in the first round of dissemination of knowledge. Besides the participating members in a research project, users would include policy makers, scholars and communicators who are kept directly informed of the research and its results.

Some of the $\mathrm{Z}$ interactions are much more intensive and manifold than others. For example, the interaction cell RIDI which joins together the donor funding institution and the recipient sponsoring institution is a necessary chain in all types of educational research. The interactions in this cell are usually many-sided: formal, political, administrative and financial.

Cell R2D2 is where the analysts from both worlds interact in the execution of the research proper. Moving along the diagonal, cell R3D3 is applicable in so far as exchange of knowledge and related experience between users in both worlds is made feasible by incorporating seminars and exchanges in the research programme.

Interactions along the diagonal are between actors who, although foreign to each other, do communicate in common languages and follow similar rules of accountability in the execution of their functions. The interactions in the remaining cells are between notalikes. For most types of educational research, these interactions are shallow and formal in the lifetime of a research project, but can assume important roles in the extension of the research, initiation of new research, subcontracting etc.

Within the donor country (or international agency) there is a very lively process of interactions between competitive sponsors, alternative analysts and alternative users which ends up in 'losers' and 'winners' who become the sponsor, analyst and user; and who determine the specific shape of the educational research as far as the donor is concerned. This competitive environment is demonstrated in the right hand upper matrix of Figure 2. A similar competitive process among alternative sponsors, analysts and users occurs in the recipient country culiminating in the recipient's particular combination of actors and their specific shaping of the educational research as demonstrated in the left hand lower matrix of Figure 2. The relationships between both groups of actors are the subject matter of the third matrix.

The scheme draws attention to the existing communication between alternative sponsors in donor and recipient countries, as well as alternative analysts and alternative users in both worlds. As far as a particular project is concerned, the winning actors are shown vertically for the donor and horizontally for the recipient country. The ultimate shape of a particular project can be rightly described as the result of a large number of unsuccessful and successful communications between alternative candidates, and a number of more specific interactions between the ultimate actors as represented by $X$ (in the donor), by $Y$ (in the recipient) and by $Z$ (in the donor/recipient relationships).

Furthermore, the communication network creates possibilities for the losers to join hands and plant the seeds for the next educational research. Such a collaboration would appear in Figure 2 in the undrawn matrix in the upper left hand quarter.

There is only fragmented documentation on the processes outlined above. One of the rare illustrations is in a recent paper on Latin America [Schiefelbein 1983] where it is reported that in that region $20 \mathrm{UN}$ agencies (and their decentralised units), eight regional organisations, 10 donor agencies and 13 private organisations are active in sponsoring networks related to education and are involved, in one way or another, in sponsoring the production and/or consumption of educational research. The author comments: 
Extended Interactions in ERDC
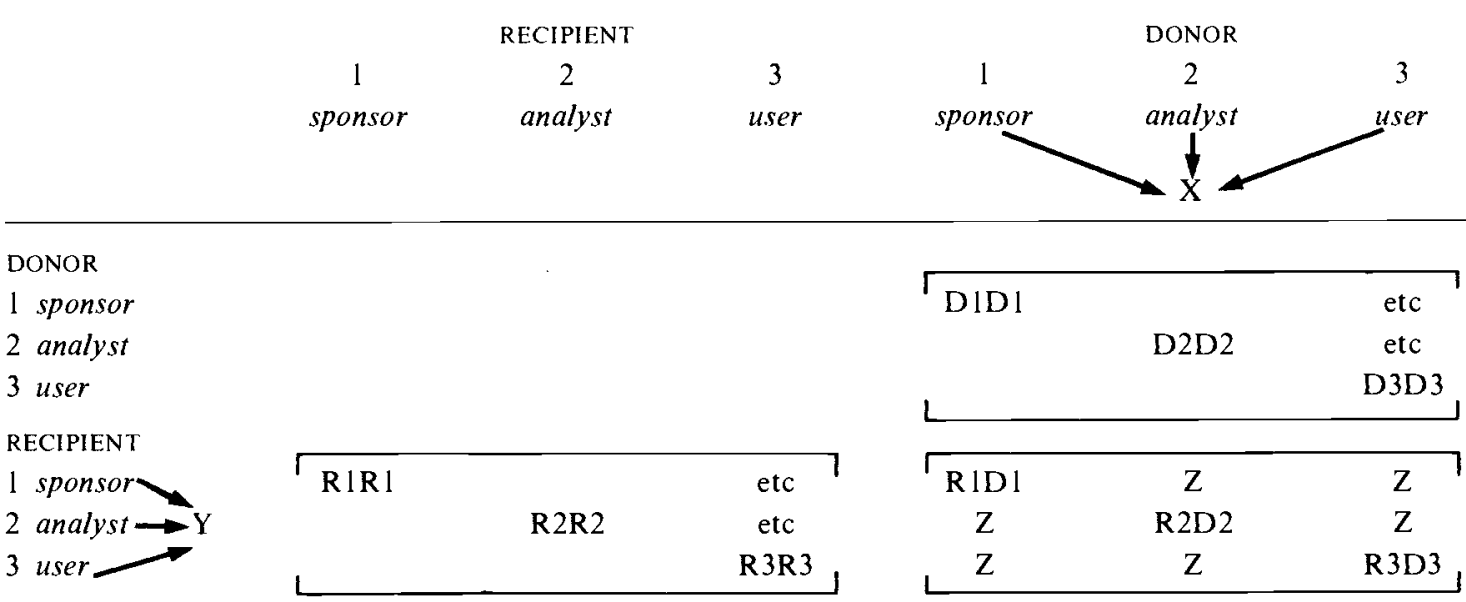

Several circuit-riders have acted as brokers of information articulating both the demands and the available bits of answers ... [ [they] are detecting new needs as well as new sources of information or suggesting ways in which old sources may be used to shed light onto new issues. As a rule of thumb, half of the proposals for new research may be redundant because results of similar research are already available in typed or hand-written notes resting in a drawer.

This observation can be underscored by many of us who are involved in the process of educational project identification and preparation for multilateral or bilateral donors. To emphasise the need to document Figure 2, attention is drawn to Spaulding [1981].

\section{Applicability of the International Interactions to a Typology of Educational Research}

Among the most commonly accepted typologies of educational research is that of Jean-Pierre Vielle [1981]. It is particularly suitable in the present context where ERDC is seen as an interactive process. We shall adapt his classification with a minor modification and display the degree of intensity of interactions for each type in Table 1.

Vielle distinguishes four main types of research:

\section{Disciplinary research}

This includes projects that analyse and evaluate educational phenomena in terms of the interaction among their variables or of the links between education and the rest of society.

\section{Instrumental research}

Here are included projects that have as their immediate objective the introduction of change in educational contents, procedures, technologies and systems.

\section{Action research}

These are projects that directly undertake to alter the educational process in a new and often experimental way.

Policy research (or what Vielle calls planning research)

This includes projects that seek to evaluate, diagnose and forecast the course of educational systems; that design plans and educational programmes; that define the roles to be assumed and the strategies of action to be undertaken.

In addition to these, Vielle distinguishes between bibliographical/statistical research and research on research. Naturally, concrete projects may contain elements of various types.

Subject to exceptions, the four main types of ERDC can be stylised in terms of their associated characteristics. According to Myers [1980], in the early seventies, disciplinary research and instrumental research (learning or teaching processes) may have formed about two thirds of studies identified as ERDC in Africa. This is consistent with an overwhelming dominance of educators among the researchers (almost four-fifths). Action research is relatively 
minor in terms of its spread and resources. Policy research is the other major type accounting for about one-third of studies in ERDC and carried out by economists and other social scientists (about onefifth). In Asia and Latin America, the representation of educators $v i s-\dot{a}$-vis economists, social and political scientists may be somewhat more balanced. It is probable that in the early eighties, economic applications have increased appreciably, as seems to be evident from the next section.

Besides Vielle's classification, it is valid to disaggregate ERDC into two general categories in conformity with the political prestige assigned to the particular projects by donor and recipient governments. They may be named very important projects (VIP) and much less important projects (LIP). Examples of the VIP are those which require a formal accord and signature by the minister/ambassador. The projects have large budgets, several components and a relatively large research team. Use is made of acknowledged expertise. There is a high incidence of governmental documents, as well as a high degree of access to the results but the researchers are usually less autonomous than in other contexts. By contrast, the LIP-type projects are small, involve lower level officials, their researchers may be younger and administrative facilities are minimal. The interaction of the reactors is likely to be as hypothesised in Table 1 . The intensity of the interactions and the quantity and type of problems faced would depend, of course, on whether the research is what we call VIP or LIP

Should one agree on the usefulness of analysing ERDC as an interactive process and on the research typologies above, the hypothetical interactions in Table 1 can be readily subjected to refutation and verification, and a more realistic picture thus attained.

The effectiveness of ERDC, as of other research, depends on the extensiveness and intensiveness of communicating the research. The table gives a starting point for appraising the intensiveness and extensiveness of the communication network of typical activities of ERDC. The table shows some activities, like disciplinary research, to be deficient in their communication network and possibly in need of a broadening of network. The table suggests, for other activities with a high intensity of communication, that what may be needed is better prepared attitudes, deeper understanding and more acquaintance between partners as well as more clearly defined rules for regulating the increasingly complex, but highly desirable, communication networks.
Table I

Intensity of interactions by typology of ERDC

DONOR 1 sponsor 2 analyst 3 user

RECIPIENT

\begin{tabular}{|c|c|c|c|}
\hline 1 sponsor & $\begin{array}{l}\mathrm{a}+ \\
\mathrm{b}++ \\
\mathrm{c}++ \\
\mathrm{di}++ \\
\mathrm{dii} \mathrm{v}\end{array}$ & $\begin{array}{l}\mathrm{a}+ \\
\mathrm{b}+ \\
\mathrm{c}+ \\
\mathrm{di}++ \\
\mathrm{dii}+\end{array}$ & $\begin{array}{ll}\text { a } & o \\
\text { b } & o \\
\text { c } & o \\
\text { di } & o \\
\text { dii } & +\end{array}$ \\
\hline 2 analyst & $\begin{array}{ll}\mathrm{a} & 0 \\
\mathrm{~b} & \mathrm{o} \\
\mathrm{c}+ \\
\mathrm{di}+ \\
\mathrm{dij}+\end{array}$ & $\begin{array}{l}\mathrm{a}+ \\
\mathrm{b}++ \\
\mathrm{c}++ \\
\text { di }++ \\
\text { dii } v\end{array}$ & $\begin{array}{ll}\text { a } & o \\
\text { b } & o \\
\text { c } & o \\
\text { di } & o \\
\text { dii } & +\end{array}$ \\
\hline 3 user & $\begin{array}{ll}\mathrm{a} & \mathrm{o} \\
\mathrm{b} & \mathrm{o} \\
\mathrm{c} & \mathrm{o} \\
\mathrm{di} & + \\
\mathrm{dii} & +\end{array}$ & $\begin{array}{l}\mathrm{a} o \\
\mathrm{~b}+ \\
\mathrm{c}+ \\
\mathrm{di}++ \\
\text { dii }++\end{array}$ & $\begin{array}{l}a v \\
b+ \\
c \quad v \\
\text { di } v \\
\text { dii } v\end{array}$ \\
\hline
\end{tabular}

$\mathrm{a}=$ disciplinary research, $\mathrm{b}=$ instrumental research, $\mathrm{c}=$ action research, $\mathrm{di}=$ institutionalised policy research, $\mathrm{dii}=\mathrm{irregular}$ policy research, $o,+,++$ represent increasing degree of intensity, $v$ represents a variable degree of intensity depending on project specification.

\section{The Case of the Donor Country}

In general, there is very little documented on the functioning of funding agencies and researchers in donor countries - the $\mathrm{X}$ interactions. The account here is based on the personal experience of the authors and is more applicable to research activities of the policy type than other types.

The situation is such that the sponsor, who is mostly a governmental agency, has policy guidelines for spending, a budget to spend and a communication network with possible project implementers (the analysts or their research managers). Almost simultaneously, the sponsor in the donor country would seek a green light from the sponsor in the recipient country, and the analyst in the donor country would do the same with the counterpart researchers in the recipient country; of ten under the auspices of their respective sponsors. Given the specialised nature of proposals advanced by the analyst, it is customary that the donor is aided by appraisals from advisors. Since the proposal (later the project document) is the reference for the sponsor, by which he can account for his responsibility to his superior, the sponsor is very 
careful that any project document, and its manning, is consistent with the guidelines. Awareness of the rules of the game for the sponsor has tended to orient researchers to organise themselves and prepare exactly those scripts which conform with the guidelines.

The collaboration between the funder and the analyst in the donor country brings to light deficiencies which are not particular to ERDC. They are rather the result of increased centralisation, scarcity and professionalisation of funding, and of a tendency for quasiscientific research and research management to infiltrate and subordinate scientific research to funding considerations. Several aspects may be highlighted in this regard:

- policy guidelines for sponsors are very general statements with a high frequency of replacement and rewording. The capacity of the sponsors to transform these guidelines into unambiguous regulations tends to be low. The situation leads to arbitrary decisions and unclear minds;

- eagerness to consolidate goodwill between funding agencies and research institutions has led the latter to orient themselves excessively to satisfying the requirements of the former and to insufficient regard for the criteria of necessary and good science;

- the sponsor in a small donor country does not have the capacity to judge the product and its quality. The incapacity to pass judgement on substantial matters had led the sponsor to give excessive emphasis to procedural matters;

- the minimal dissemination of knowledge is often not achieved. The reason is that the information collected in the field is rudimentary and requires consolidation before it can be made readable to the scientific community. However, there is hardly any provision by the sponsor for this.

\section{The Case of the Recipient Country \\ General}

King Gordon [1982] quotes Jan Pronk when he launched the Netherlands national advisory body on research policy and priorities in 1977:

Development related research can be aimed at analysing the processes that cause poverty. It can also pinpoint the instruments with which the asssistance can most effectively achieve the goals of Dutch development policy. But research that is relevant to development can also promote the selfreliance policy of developing countries. It is now increasingly recogised that development is primarily a question of the poorest population groups and their basic needs. If any research is to be relevant to development, whether in the first, second or third case, it must ultimately be directed to these people.

Agreed. But when the criteria above are translated into the realities of the education sector in most developing countries, they would appear to give no weight to a number of very complex real problems, which do arise and have to be catered for in any formulation of criteria, if such criteria are to be operationally useful. Several of these problems will be illustrated below in Figures 3, 4 and 5.

In general, political statement on desirable aims, if it is to be useful, should consider the factual situation. Myers [1980] in a survey of developments in educational research in Latin America (which could be equally valid for other regions of the Third World) reflects on the situation in a recipient country as follows:

The cases presented suggest that, in general, institutionalised research in the Third World is: new, growing rapidly, under-financed, uncoordinated, fragile, still dominated by a tradition of psychopedagogical research, unable to train locally a next generation, subject to international funds, dependent on First World concepts and methodologies, and living on its own potential. With few exceptions, growth is tied to foreign assistance and often to key individuals within a country or a region. Direct, informal contacts are still more important for diffusing research than is the written word. Everywhere, potential consumers of educational research remain a small and select group; a research mentality is not spread within nations.

\section{Information, research and aid flows}

From a recipient point of view, everyone involved in education is by definition both a consumer and a producer of information; research results are often conceived as being one of the components to be integrated into the existing stock of a country's knowledge about interrelationships within the educational system and of education with other subsystems. The links of internally financed research efforts with those supported through cooperation with foreign bodies can thus be visualised as in Figure 3 [Reiff 1980]. 
Educational information and research flows in a recipient country

Feedback: quality/relevance of information/research

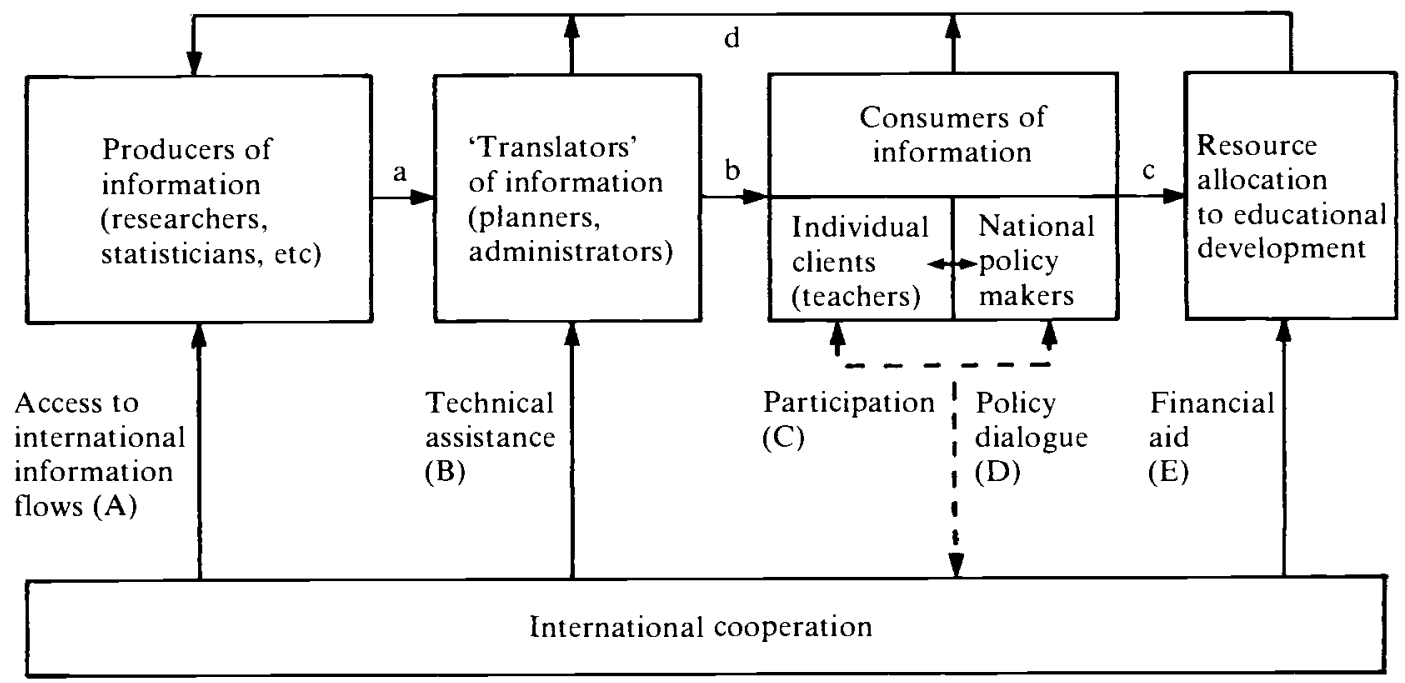

\section{Internal flows in Figure 3}

a - How do officials mix the knowledge emerging from research with other types of information in a packaged form which can be absorbed by planners and administrators?

b - How and through which networks and modalities does information on more desirable behaviour reach consumers: the public sector, the teacher and the individual in the private sector?

$c$ - How and in what combination do national educational policy makers use knowledge in deciding on resource allocation to education over time (short and medium term plans) and space (geographical distribution), given major policy directions? Also, how is ' $c$ ' influenced by ' $E$ ', ie international financial aid?

d - Accountability of relevance/quality of educational research: evaluation studies which enhance the flow of information back to the research community.

\section{Foreign flows in Figure 3}

A - Research proposals as a function also of universally available knowledge, internationally standardised statistical classifications; etc.

B - Training (with substantial research components) and advisory services (including dissemination of relevant research outcomes).

C - Participation of individuals in international dialogue often through non-governmental organisations.

D - Ministerial conferences at international and regional levels.

E - Aid (project-tied research focused on efficiency).

Figure 3 encapsulates a number of problematic relationships, which Figure 4 attempts to unpack. 
Research, development and basic needs in education; identifying some major interactions

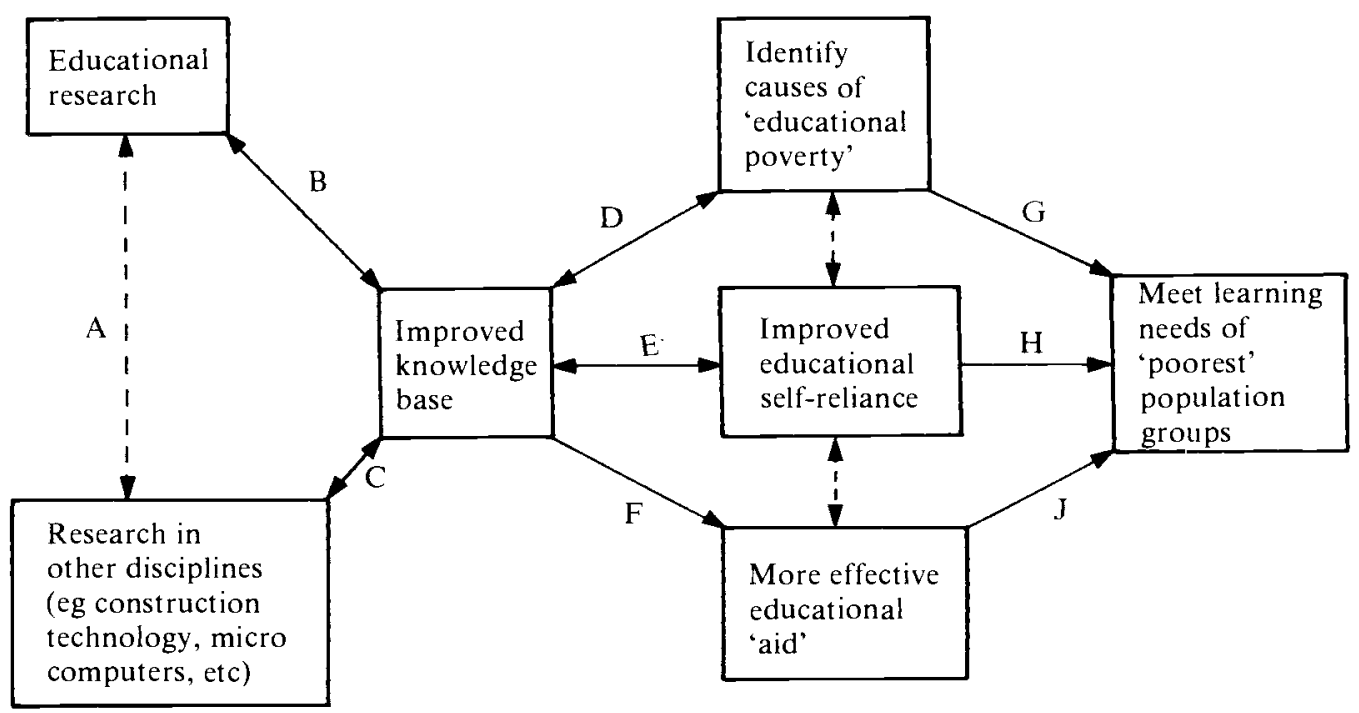

\section{Issues in Figure 4}

A - Problems of coordination (emerging new research paradigms?), also with research in the private sector.

B -- Who 'filters' research before it becomes integrated into the existing stock of knowledge?

C - How do research results in such areas as school construction, computer technology, etc reach the educational decision maker?

D - The 'real' knowledge base of poverty (including educational poverty) is available only locally, ie dispersed over thousands of villages and schools, millions of households and difficult to search or aggregate.

E, F - There is not (yet) a research paradigm for investigating these interrelationships.
G - Attitudes rarely permit experimentation, development or a generalisation of successful educational innovations.

$\mathrm{H}$ - 'Self-reliance' implies enhancing national research/management capacities which, in turn, can imply more resources for higher education and less available for basic education/basic needs oriented activities.

$\mathbf{J}$ - Can educational 'aid' be directed to and absorbed by marginal (out-of-school) population groups directly?

Reality in the recipient country is still much more complex than these accounts of issues and problems would suggest. Figure 5 gives additional insight regarding funding and quality/relevance of the product. From the view of those responsible for educational research in a recipient country, the world around would more or less fall into four dimensions. 
Cooperation in educational research; an identification of primary and secondary streams

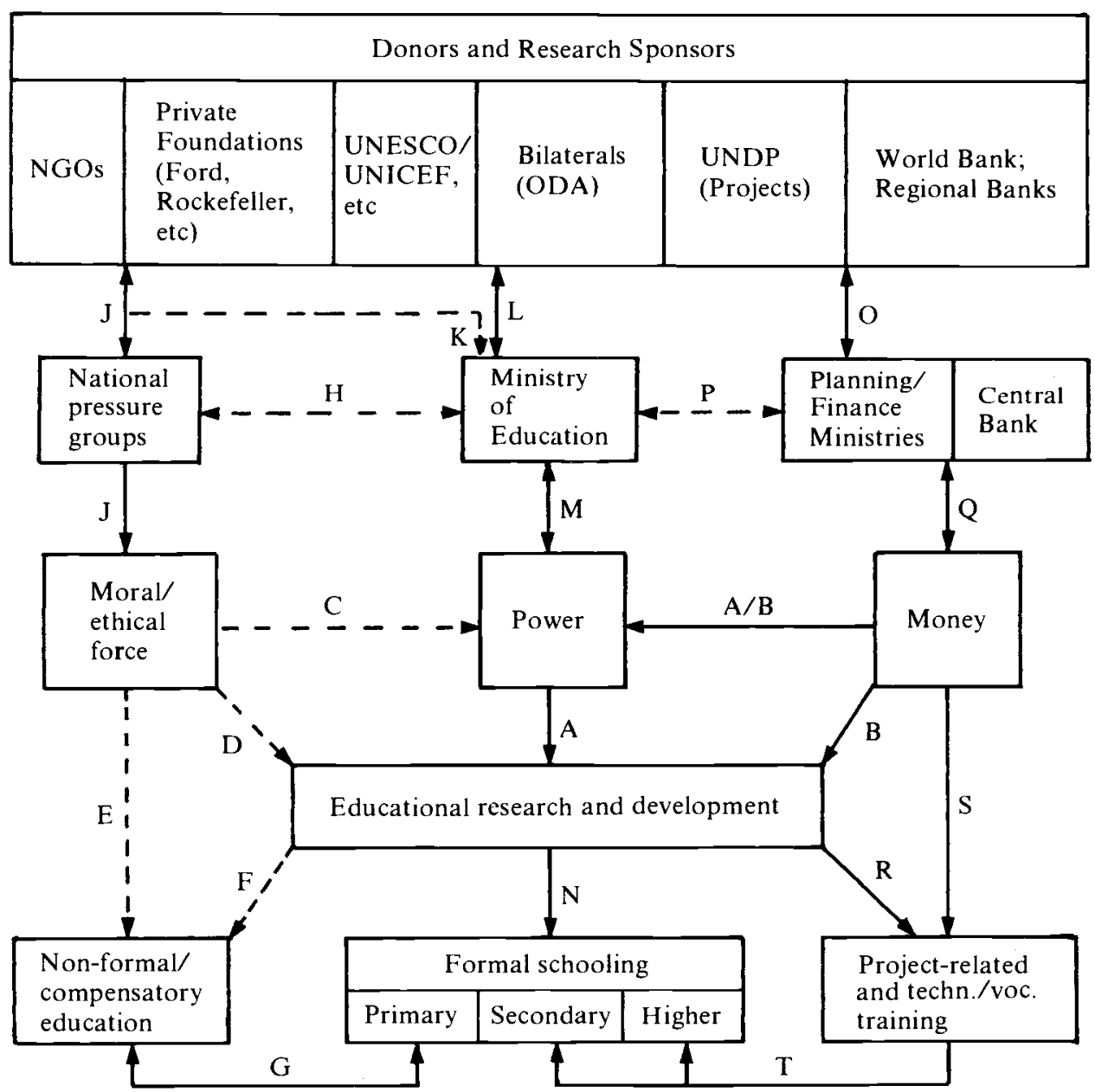

\section{Explaining Figure 5}

i) Educational development and research is determined by a mixture of power $(\mathrm{A}=$ strong $)$ and money $(B=$ strong), mutually reinforcing each other (A/B), with some influence from moral/ethical forces in society either indirectly, through power $(\mathrm{C}=$ unions'/parties' impact on parliament $=$ weak) or $\operatorname{directly}(\mathrm{D}=$ impact of teachers' associations, parents' organisations, pressure from representatives of underprivileged population groups, etc).

ii) On the left side of the chart, the moral/ethical forces which would promote the development of (non- formal) compensatory education (E) to meet the educational needs of underprivileged population groups and research activities related to an identification of these needs $(F)$ remain relatively weak in most countries.

iii) In the centre of the chart, the relations are clear and require little comment. Bilateral and international agencies in dialogue (L) with the Ministry of Education, strengthen $(M)$ the power base underlying the national educational policy and the current Five Year Educational Plan (A). 
iv) On the right of the diagram, the national educational researcher can and does observe the major patterns in which 'money' (development funds for education), negotiated between major external donors (eg UNDP, World Bank, Regional Banks) the Central Bank (IMF criteria), the Ministries of Finance and Planning and the Ministry of Education, influences educational development and research (lines $\mathrm{O}, \mathrm{P}, \mathrm{Q}$ and B). However, it is much more difficult for him/her to assess how information and research requirements from the donor's side (eg tracer studies, school mapping exercises) preempt a fragile research capacity which could have been mobilised to undertake more fundamental/anthropologically-based educational research (eg learning process of the child) not directly related to the efficiency criteria of investment in educational projects. The combination in which monetary flows (including the cost of foreign expertise) and information/research influence the identification and execution of educational projects (lines B and R) is often difficult to assess. However, one can detect a certain concentration of aid flows (S) to project-related and technical/vocational training which is also reflected by a relatively abundant volume of research $(\mathbf{R})$ in this field, such as manpower studies, tracer studies, education/training - productivity research, human resources development models, etc. Even a neut ral research institute like the International Institute for Educational Planning (IIEP), lists in its catalogue of publications over the period 1978-83 [IIEP 1983] about 35 recent studies in the areas of manpower/employment which relate to vocational/ technical and higher education as against about 50 studies in all other subject areas combined. This general trend, which can also be observed (less surprisingly) in the publication catalogues of the World Bank, seems to point to a certain bias of research taking place on technical and higher education (T). Much less research seems to be sponsored internationally for preprimary and primary education. It is interesting to note that the results of a study by NUFFIC [1984] for the Dutch ERDC are consistent with these general trends.

In this 'jungle' of information and financial streams, the national researchers in the recipient country would require support in: a) clarifying the above picture; b) stimulating the interaction between the stock of indigenous knowledge and the definition of objectives and evaluative criteria in education; c) testing the relevance of externally acquired knowledge in terms of its usefulness in specific socio-cultural settings and forms of social authority; d) screening imports of foreign knowledge and/or research paradigms in case these are in disharmony with endogenous processes of creating, manipulating, forecasting and using knowledge in educational development; e) estimating the cost-effectiveness of combining scarce research resources with an abundant participatory potential in searching for local solutions to local problems.

\section{Donor and Recipient Research Funding: Magnitudes and Qualities}

\section{The national funding of ERDC research}

There are very few financial data collected systematically, and even less published, in the area of funding educational research. In some of the project appraisal reports and other internal documentation of the World Bank (for official use only), one can sometimes find useful but partial information. Other donors and sponsors in the area of educational research do not report on national budget allocations in this area. King Gordon's [1982], detailed survey of cooperative efforts in education by bilateral and multilateral development cooperation agencies offers no comparison between financial/material resource flows and national outlays for educational research.

Not only is there a 'mix' of research, education and training which cannot easily be disaggregated, but also it is not clear what proportion of the total budget under this heading directly or indirectly strengthens national research capacities (on Third World issues) and what proportion goes to (and stays in) the developing countries.

In the absence of more specific country data in this area, a more global 'macro approach' might at least give us some ideas about the order of magnitude of national spending on educational research. Statistical information abstracted from the UNESCO Statistical Yearbook [1983], the World Bank Atlas [1983] and the OECD Review of Development Cooperation suggest some tentative observations:

i) The share of all expenditure on research and experimentation (including defence) which is allocated to the higher education sector is considerable, with averages of about 7 per cent for $A$ frica (ranges $1-15$ per cent), 20 per cent for Latin America (ranges 5-30 per cent), 10 per cent for Asia/Arab States (ranges 2-30 per cent), 19 for the developed $O E C D$ countries (ranges 10-30 per cent) and 15 per cent for the East European centrally planned countries.

ii) If we compare expenditure on research and experimentation in higher education with total educational expenditures (all types/levels), we can observe the following average percentages: Africa: 0.4 per cent, Latin America: 1.8 per cent (ranges 0.3-4.5 per cent ), Asia/Arab States: 1.6 per cent (ranges 0.3-2.7 per cent), OECD countries: 6.2 per cent (ranges 1-10 per cent), East European centrally planned countries: 4.8 per cent 
iii) When comparing expenditure on research and experimentation in the higher education sector with total educational expenditure on higher education, we arrive at the following average figures: Africa: $2.3 \mathrm{per}$ cent (ranges 0.2-3.5 per cent), Latin America: 6.5 per cent (ranges 2-19 per cent), Asia/Arab States: 7.2 per cent (ranges 2-27 per cent), $O E C D$ countries (excluding Japan): 26.9 per cent (ranges 4-65 per cent), East European centrally planned countries, 30.8 per cent.

iv) Fourteen donor countries allocated about 14 per cent of their total bilateral aid to assistance in the education sector (ranges Japan: 3.7 per cent to France: 32.0 per cent)

What tentative conclusions can we draw from the above statistical evidence?

- Information from a limited number of OECD countries would indicate that none of them allocate more than 10 per cent of their bilateral aid for education to the strengthening of educational research capacities in recipient countries. If we were to apply this 10 'maximum' percentage to the combined bilateral educational aid from 14 OECD countries, we arrive at a total estimate of US $\$ 250 \mathrm{mn}$ representing about $\mathrm{I}$ per cent of their national investment in research/experimentation in their own education sectors.

- Bilateral aid to education by the OECD countries represents slightly over 10 per cent of their national investment in research/experimentation carried out in the education sector.

- On average, the OECD countries and the centrally planned economies of Eastern Europe spend between 5 to 6 per cent of their educational budgets (25-30 per cent of their budgets for higher education) on educational research and experimentation, while developing countries spend on this activity less than 2 per cent of their educational budget (5-6 per cent of their budget for higher education). This considerable gap (3:1) between industrialised and developing count ries is not likely to decrease in the foreseeable future. The role of international cooperation in this area is likely to remain marginal in terms of financial flows. As an example, a country like Brazil spends already more on research/experimentation in the education sector than the estimated combined aid from OECD countries in this area. Many discussions on the foreign funding of ERDC seem to be unaware of these facts.

If one considers the allocation of ERDC resources to research topics, one finds that the volume of financial resources invested in project-tied educational research and evaluation is often relatively significant. As an example, the World Bank relates research and experimentation directly to improvements in the efficiency of education and projects [World Bank, 1980, table 7]. For the period 1979-83, about 2 I per cent of the total lending in education (US $\$ 600 \mathrm{mn}$ ) will be devoted to general institutional development, usually supported by educational research in such areas as educational finance, cost-effectiveness, cost benefit and manpower studies, school-mapping, etc (a principal concern with economists). Apart from research carried out by the Bank itself, financed by the research budget of the Research Committee (almost $\$ 900,000$ over the period 1975-78) and from Departmental Funds [see Psacharopoulos 1983 for published results], it is difficult to assess the magnitude, direction and results of project-related research which is the responsibility of the borrowers (different ministries) and in which the World Bank's role is an advisory and supervisory one. However, an initial comparison between research results published by the World Bank and the educational research projects reported in the Bank's appraisal reports would suggest that the research topics generated so far have originated principally through individual initiative and the academic interests of Bank staff and that the advisory role of the Bank is often quite influential in this area.

An at tempt was made also to summarise 'studies and evaluation' inputs into primary education projects supported by the World Bank in eight developing countries. The funds for this purpose are quite considerable, ranging from about US $\$ 3 \mathrm{mn}$ in Colombia and the Philippines to over US $\$ 6$ mn ( 17 per cent of total credit) in Bangladesh. One also observes that, contrary to what one could expect from the growing academic literature in the area of non-formal education and training, few governments have proposed studies in this particular area. The relative focus on 'research-educational efficiency' and human resource development seems to be one of the major concerns.

\section{Towards a Rationale for Reforming ERDC}

The complexity of situating educational research within the total processes of information and knowledge creation and transfer, and of assessing its use in educational decision making is overwhelming and the introduction of the keywords of accountability and quality does not simplify matters. Nevertheless, the conceptualisation of such notions has helped in directing attention to five accessible levels for taking effective action towards developing ERDC. This section discusses these five areas, which we shall briefly identify as:

- harmonisation of actor accountability;

- unification of educational development; 
- mobilisation of educational planners;

- responsive awareness, and

- positive attitudes.

First, accountability suggests a measure of comparing means with ends or resources with impact. But in the context of heterogeneous interactions such a concept loses its neutrality. As the volume and direction of educational research is the result of interactions among funders, analysts and users, accountability is subject to individual interpretations at the actor level. Accountability becomes a weighing of duties and privileges for each actor apart. Only when these duties and privileges are in harmony can one speak sensibly of norms of accountability which are acceptable to the diverging parties, viz social accountability. In such a situation, an effort at easing friction between actors will have greater returns than the construction of yet another idealistic system of norms which has little chance of becoming acceptable and operational.

A piecemeal approach by which certain inconveniences in the interaction between sponsor, analyst and user can be identified and resolved may contribute a great deal towards a harmonisation of individual accountability.

Secondly, a unification of educational development across disciplinary boundaries would increase the effective functioning of ERDC. Quality and relevance can only be measured against some standards or norms which must emerge from an interdisciplinary theory of education or of learning. Such a theory does not (as yet) exist and is slow in coming, as long as educators do not seem to agree on a research paradigm which can be tested universally. As a consequence, the quality of educational research is being measured mainly against indicat ors of a) internal consistency in the treatment of 'true' and 'honest' data through a balanced package of research instruments and b) external relevance to felt and/or expressed information needs situated as close as possible to the target population. And regarding needs in education these are researchable only through an interdisciplinary approach, education being integrally linked into a 'seamless web', of nutrition/health/family welfare and learning/employment/income/quality of life. With the exception of a few intersectoral research undertakings, few reseach institutions combine the mix of disciplines which would permit them to enter this difficult but socially accountable area, where preliminary results are often inconclusive in nature and mainly helpful in the development of a long term research strategy. A greater integration of the knowledge which already exists in different disciplines is badly needed to substitute for the overfragmentation of ERDC.
Of course, given increased resource constraints in education in both donor and recipient countries, some rational choices will need to be made regarding research priorities in education. Any agenda on which sponsor/brokers, producers and consumers of educational research will have to meet in the future would therefore need to rationalise its choices in terms of: more efficient use of researchers; use of nonconventional knowledge bases (interdisciplinarity); cautious use of 'soft' or intuitive hypotheses; and the de-bureaucratisation of research.

Third, one of the main functions of educational planners is to synthesise and translate the knowledge resulting from research in education and in relevant branches of the social and human sciences into guidelines for policy formulation and implementation. The educational planner is thus performing the role of the middleman between the researcher and the decision maker. Theeducational planner becomes an important safeguard against the arbitrariness which may creep into ERDC.

The role of educational planning in promoting such an exchange of policy-relevant information depends largely on the volume and types of information which can be identified and absorbed. In most developing countries, educational planners spend most of their time and energy on project/programme design and evaluation (to fit the formats of the different donors and their own national ones), at the expense of the important tasks of analysing, computing and projecting information in order to allow the policy maker to make rational or scientifically sound decisions. It is suggested that a mobilisation of educational planners for developing ERDC should be strengthened in this respect. Policy makers should find ways of doing this.

Fourth, responsive awareness would eventually lead to developing and appreciating alternative structures for conducting ERDC. In contrast to the piecemeal remedies of the preceding paragraphs, what is implied here is a long term crusade to publicise practices which are felt to be unacceptable. In particular, there has been comment on some ERDC which takes place in institutes of higher education or in specialised research institutions, either in the developed or developing countries. Cooperation in strengthening institutional capacities in this area rarely involves the researched target group (teachers, pupils, parents). In many countries, universities are elitist in nature and their interests are in close harmony with power (the government) and money (the planning agency and the donors). As the research process in education is thus mainly a vertical flow downwards (hardly justifiable with claims that 'grass-root' information is being used), the question remains whether its results 'trickle 
down' (implying equitable distribution to all potential users) or 'filter down' (implying efficient use by a few decision makers). The process of trickling down follows more or less the shape of the educational pyramid.

It is often hampered by a lack of interest and resources to communicate the research outcomes to the lowest levels of decision making, ie the educational district officer, the school teacher, the household and the individual. As a result, only a very thin filtering down process to the ultimate users occurs.

Such a critique can lead to responsive awareness, only if it is well documented on a case by case basis and given sufficient publicity via various media. In this connection, an increased emphasis on research on educational research will allow us to analyse effectively these largely unknown processes and, eventually, be able to smooth friction points between actors and contribute to forming a consensus on social accountability.

Fifth, the promotion of desirable changes in attitudes of persons involved in ERDC is of a longer term nature, and yet any small movement in the right direction is worthwhile. What is the right direction? And how to promote it? We may suggest what is the right direction, but the how is itself an educational process.

There is a popular claim in ERDC that 'imperialistic' educational research paradigms (whether based on a modernisation theory or a dependency theory of educational development) have been imposed on a fragile national research community in developing countries. Whether this claim is true or false may be less significant than the attitude which may lie behind such claims. Such an attitude may reflect a belief in the inability of the developing country's organisers, producers and users of ERDC to determine what is best for them and their people. We wish to postulate that these are negative attitudes, and that positive attitudes which manifest confidence on both donor and recipient sides are prerequisites for assuring the success of a joint effort.

As no educational research is either purely local or purely foreign in nature, the underlying raison d'etre of a meeting on educational research between developed and developing countries is the conviction that the diversity in cultural and historical developments of nations does not invalidate the effort to transfer knowledge and understanding from one situation to another or vice versa.

\section{Bibliography}

Arnove, R., 1977, "The Ford Foundation and "competence building" overseas: assumptions, approaches and outcomes', Studies in Comparative and International Development, vol 12 no 3

Coombs, Ph. et al, 1975, Education for Rural Development, International Council for Educational Development

Court, D. and P. Latapi, 1979, The Research Process, International Development Research Centre, Ottawa

Debeauvais, M., 1980, 'The role of international organisations in the evolution of applied comparative education' in Diversity and Union in Education, B. Holmes (ed), Allen \& Unwin, London

De Landsheere, G., 1982, Empirical Research in Education, IBE/UNESCO

Hudson, M. B., R. G. Davis et al, 1980, 'Knowledge networks for educational planning: issues and strategies', IIEP Research Report, UNESCO/International Institute for Educational Planning, Paris

International Institute for Educational Planning 1983, Recent IIEP Publications and Documents, Paris

Kaspizak, W. and K. Pelc, 1978, "Analysis of human needs as a basis for research policy, Technological Forecasting and Social Change, vol 12, North Holland Inc, Elsevier

King, K., 1981, 'Dilemmas of research aid; education in developing countries', Prospects, vol XI no 3

King Gordon, J., 1982, 'Priorities and problems in education for development' in Financing Educational Development, IDRC, Ottawa

Lewin, K., A. Little, and C. Colclough, 1983, 'Effects of education on development objectives (II)', Prospects, vol XIII no 4, UNESCO, Paris

Machlup, F., 1980, Knowledge and Knowledge Production, Princeton University Press, Princeton

Myers, Robert G., 1980, Connecting Worlds; a survey of developments in educational research, IDRC, Ottawa

NUFFIC, 1984, Inquiry on Education Research in Developing Countries: an inventory of Dutch projects and programmes, (in Dutch)

Papagiannis, G., 1982, 'Towards a political economy of educational innovation', Review' of Education Research, vol 52 no 2

Phillips, H. M., 1981, "Criteria and methods of generating education cooperation projects for external funding', Comparative Education, vol 17 no 2

Psacharopoulos, G., 1983, "Educational research at the World Bank', IBRD Research New's, vol 4 no 1, Spring 
Reiff, H., 1980, 'Communication channels for educational policy' in $\mathrm{G}$. Psacharopoulos (ed), Information: an essential factor in educational planning and policy, UNESCO, Paris

- 1983, "International cooperation in education: five suggestions for educational planning and policy research', UNESCO/International Institute for Educational Planning, Paris, mimeo

-1983, "International cooperation in education with the least developed countries", Prospects, vol XI11 no 4

Schiefelbein, E., 1983, "The role of research in the conception and implementation of educational policies: the Latin American Experience', UNESCO/International Institute for Educational Planning, Paris, mimeo

Simkin, K., 1981, 'Comparative and sociological perspectives on Third World development in education', International Revie' of Education, vol 27 no 4
Spaulding, S., 1981, 'The impact of international assistance organisations on the development of education', Prospects, vol Xl no 4

UNESCO, 1983, Second Medium-Term Plan (1984-89)

-1983, Statistical Yearbook 1983, Paris

Vielle, Jean-Pierre, 1981, 'The impact of research on educational change, Prospects, vol Xl no 3

Weiler, H., 1983, 'The politics of educational planning: notes on the political economy of education and development", Working paper, IIEP

World Bank, 1980, 'Education sector policy paper', Washington 